\title{
Presentation by Angel Horna
}

\author{
Legal Adviser, Permanent Mission of Peru to the United Nations
}

One of the mandates of the United Nations General Assembly, contained in Article 13 of the Charter of the United Nations, refers to the initiation of studies and the making of recommendations to encourage the progressive development of international law and its codification. Subsequent practice has interpreted this provision as an authorization to elaborate new international conventions on a wide range of issues - in particular, through the work of the International Law Commission, which is later considered by the General Assembly, through its Sixth (Legal) Committee. This should contribute to establishing "conditions under which justice and respect for the obligations arising from treaties and other sources of international law can be maintained". ${ }^{1}$ Against this backdrop, this article reflects on the relationship between those two bodies.

\section{In what ways have the Sixth Committee and the International Law Commission interacted, formally and informally, to advance the progressive development of international law and its codification?}

The contribution of the International Law Commission to the progressive development of international law and its codification depends to a large extent on the dialogue and cooperation with the Sixth Committee. Due account must be taken of the necessary definition and distinction of their respective roles. ${ }^{2}$ The International Law Commission, composed of legal experts, plays a scientific role. In turn, the Sixth Committee offers policy guidance to the Commission through comments by government representatives with strong legal backgrounds, who are also mindful of political sensitivities. ${ }^{3}$

With respect to cooperation between the two bodies, responsiveness is sometimes insufficient. Indeed, there has been criticism regarding governments' failure to answer questionnaires or submit comments and observations requested by the Commission. However, a lack of response does not necessarily

1 Charter of the United Nations, preamble.

2 One author would say "complementarity, not identification", see Alain Pellet, 'Between Codification and Progressive Development of the Law: Some Reflections from the ILC' (2004) International Law FORUM du droit international 15.

3 For early reflections on "hombres de estado" versus "juristas eminentes" regarding codification, see Alberto Ulloa, Derecho Internacional Público, vol 1 (4th edn, Ediciones Iberoamericanas 1957) 88 . 
indicate disinterest. Instead, there are often logistical challenges, including difficulties in obtaining pertinent information from national authorities within the time frame allotted by the Commission.

Regarding formal interactions, the annual presentation of the report of the Commission to the Sixth Committee is to be highlighted, in particular within the framework of the International Law Week. ${ }^{4}$ This interaction serves in some way to institutionalize the dialogue between the two bodies, which is followed by a debate and the adoption of the annual resolution of the Sixth Committee. ${ }^{5}$ To this, one should add the formal submissions of comments and observations on the outcomes of the Commission, especially between first and second readings.

An important informal element of the dialogue and interaction between the International Law Commission and the Sixth Committee are side events organized by Permanent Missions to the United Nations in New York. They provide an opportunity for Special Rapporteurs, as well as other members of the Commission, to make informal presentations about topics of interest, to facilitate exchanges of views and sometimes a substantial informal discussion, which strengthens the interaction between Member States and the Commission.

\section{How Have the Bodies Influenced Each Other? What Have Been the Joint Achievements and the Difficulties?}

Concerning mutual influence, some members of the Commission are former delegates to the Sixth Committee, which shows the existence of "common views". Although less frequent, there are also instances in which a member of the Commission subsequently became a representative in the Sixth Committee. ${ }^{6}$

Another example of mutual influence is that some outcomes of the Commission have been taken up by the Sixth Committee or, even, by intergovernmental conferences, for codification. As joint achievements, several

4 The so-called "high level week" of the General Assembly's Sixth Committee, when principal legal advisers based in capitals journey to New York, coincides with the first week of the presentation of the annual report of the International Law Commission to the Sixth Committee, as well as the reports from the President of the International Court of Justice, the President of the International Residual Mechanism for Criminal Tribunals, and the President of the International Criminal Court to the General Assembly. Note that during that week there is also an annual briefing of the President of the ICJ to the Security Council, in the format of a "closed session", as well as an address of the ICJ President to the Sixth Committee.

5 Note that the author, as delegate to the Sixth Committee, was the facilitator of that annual resolution from the sixty-ninth to the seventy-third session of the General Assembly.

6 While not directly linked to the relationship between the Sixth Committee and the International Law Commission, it may be worth mentioning that since the inception of the Commission it has been possible to observe, in some cases, a "flow" between members of the Commission and judges of the International Court of Justice. 
conventions based on drafts prepared by the Commission could be identified. They include: the Vienna Convention on Diplomatic Relations (1961), ${ }^{7}$ the Vienna Convention on Consular Relations (1963), ${ }^{8}$ the Vienna Convention on the Law of Treaties (1969), ${ }^{9}$ the Convention on the Prevention and Punishment of Crimes Against Internationally Protected Persons, including Diplomatic Agents (1973), ${ }^{10}$ as well as the Convention on the Law of Non-Navigational Uses of International Water Courses (1997). ${ }^{11}$ It is noteworthy that the draft statute for an international criminal court was also elaborated by the Commission. ${ }^{12}$

In the same vein, reference can be made to the $195^{8}$ Geneva Conventions on the Law of the Sea. ${ }^{13}$ Even though not currently the applicable law on the subject-matter, they contain several provisions, including on maritime delimitation, that prevailed until their incorporation in the 1982 United Nations Convention on the Law of the Sea. ${ }^{14}$

On the other hand, there have been instances in which the work of the Commission on a given topic extended for several decades, as was the case with the draft articles on responsibility of States for internationally wrongful acts (2001). ${ }^{15}$ Another - far from ideal - example is that of the Convention on the Jurisdictional Immunities of States and Their Property: ${ }^{16}$ the Commission worked on a text between 1978 and $1991,{ }^{17}$ but the General Assembly only adopted the Convention in 2004 and it has not yet entered into force.

Notwithstanding the foregoing, the success of the Commission cannot be assessed by considering only whether its final outcomes ever came into force, or by the number of ratifications of the conventions it has produced. In fact, other factors may play an important role. For instance, the impact of the draft articles on State responsibility, even when they were in the making, has been remarkable.

$7 \quad$ Adopted 18 April 1961, entered into force 24 April 1964, 50o UNTS 95.

8 Adopted 24 April 1963, entered into force 19 March 1967, 596 UnTS 261.

9 Adopted 23 May 1969, entered into force 27 January 1980, 1155 UNTS 331.

10 Adopted 14 December 1973, entered into force 20 February 1977, 1035 UNTS 167.

11 Adopted 21 May 1997, entered into force on 17 August 2014, UNTS registration no 52106.

12 [1994] II (2) ILC Ybk 1, 26.

13 Convention on the Territorial Sea and the Contiguous Zone, adopted 29 April 1958, entered into force 10 September 1964, 516 UnTS 205; Convention on the Continental Shelf, adopted 29 April 1958, entered into force 10 June 1964, 499 UNTS 311; Convention on the High Seas; Convention on Fishing and Conservation of Living Resources of the High Seas, adopted 29 April 1958, entered into force 20 March 1966, 559 UNTS 285.

14 Adopted 1o December 1982, entered into force 16 November 1994, 1833 UNTS 3.

15 UNGA Res 56/83 (12 December 2001), annex.

16 Adopted 2 December 2004, not yet in force, UN Doc A/59/508.

17 ILC, 'Draft articles on jurisdictional immunities of States and their property and commentaries thereto' [1991] II(2) ILC Ybk 13. 
At present, it would be hard to challenge the authority of the draft articles, even though not all of their provisions reflect customary international law.

As for the difficulties facing the interaction between the two bodies, in recent years the Sixth Committee has not taken a concrete decision on the final outcomes of the Commission. There are plenty of examples of situations where - irrespective of carefully crafted recommendations by the Commission - the Sixth Committee simply decides to "take note" of such outcomes and then to consider at a later stage the question of the elaboration of a convention ("technical roll-overs"). These situations should be avoided.

Indeed, in the last 14 years, no convention has been adopted by the General Assembly, or under its auspices, on any of the topics on which the Commission had produced draft articles for codification. It is my hope that this trend will be reversed, including with the final outcome of the Commission's work on the topic crimes against humanity.

The Sixth Committee should also not turn into a forum for continuing the debates within the Commission, given that the Committee discussions should be more of a political nature and provide some guidance to the Commission.

An enhanced interaction between the two bodies could improve the chances of the International Law Commission producing outcomes that are useful to the Sixth Committee. At the same time, the Sixth Committee, through its guidance reflected in comments and observations, would also enable the Commission to produce the desired outcomes.

It would also be desirable that the Sixth Committee more actively request the Commission to include topics directly relevant to the interests of States in its programme of work. ${ }^{18}$ While this type of specific request should be

18 It should be noted, however, that in some cases issues referred by the Sixth Committee had political implications (e.g.: the question of the definition of aggression and the code of offenses against the peace and security of humanity); see, in this regard: Ian Sinclair, The International Law Commission (Grotius Publications 1987). On the other hand, the General Assembly requested the Commission, by resolution 2780 (xxvI) of 3 December 1971, "to study as soon as possible, in the light of the comments of Member States, the question of the protection and inviolability of diplomatic agents and other persons entitled to special protection under international law, with a view to preparing a set of draft articles dealing with offences committed against diplomats and other persons entitled to special protection under international law for submission to the General Assembly at the earliest date which the Commission considers appropriate". This culminated in the adoption of the Convention on the Prevention and Punishment of Crimes against Internationally Protected Persons, including Diplomatic Agents (n 10). Other examples include requests made, in accordance with article 17 of the ILC statute, through ECOSOC resolutions, such as resolution 304 D (XI) of 17 July $195^{\circ}$ and resolution 319 B (XI) of 11 August 195 . 
encouraged, the Sixth Committee, on some occasions, has chosen to establish other subsidiary bodies, such as ad-hoc committees (which were the framework in which, for instance, the sectoral counter-terrorism conventions were drafted),${ }^{19}$ special committees ${ }^{20}$ and even working groups. ${ }^{21}$

In light of the above, there are a number of practical measures that may improve the relationship between the Sixth Committee and the International Law Commission:

1. Encourage the Sixth Committee not only to endorse topics it deems appropriate for the Commission to consider (given the independent role of the Commission, pursuant to its statute), ${ }^{22}$ but to actually suggest topics. This could increase the credibility, authority and relevance of the International Law Commission.

2. In this regard, carefully consider the manner in which the Sixth Committee puts forward a request for a topic ("referral" or "terms of reference") to the Commission.

3. Consider an informal meeting between the Chair of the Commission and the Chair of the Sixth Committee, at the beginning of each session, to review the issues to be considered by the Sixth Committee, with the idea of sensitizing States.

4. Stimulate informal dialogue between States and the International Law Commission - in particular with the Special Rapporteurs - and, as far as possible, with members of academia.

5. In connection with the foregoing, consider holding a part of the Commission's session in New York from time to time, perhaps once every quinquennium, taking due account of article 12 of its statute.

19 International Convention for the Suppression of Terrorist Bombings, adopted 15 December 1997, entered into force 23 May 2001, 2149 UNTS 256; International Convention for the Suppression of the Financing of Terrorism, adopted 9 December 1999, entered into force 10 April 2002, 2178 UNTS 197; and International Convention for the Suppression of Acts of Nuclear Terrorism, adopted 13 April 2005, entered into force 7 July 2007, 2445 UNTS 89 .

20 See, e.g., the Special Committee of the Charter of the United Nations and of the Strengthening of the Role of the Organization, established in accordance with UNGA Res 3499 (Xxx) (15 December 1975).

21 For instance, a Working Group was formed in preparation of the 1997 Convention on the Law of the Non-Navigational Uses of International Watercourses (n 10), based on draft articles by the International Law Commission ([1994] II(2) ILC Ybk 89).

22 Statute of the ILC, UNGA Res 174(II) (21 November 1947) as amended by UNGA Res 485(V) (12 December 1950); Unga Res. 984(X) (3 December 1955); Unga Res 985(x) (3 December 1955) and UNGA Res 36/39 (18 November 1981). 
6. Encourage timely preparation of comments and observations from States on the work of the Commission, in the framework of the debates in the Sixth Committee, which could integrate, as appropriate, the contributions not only from the ministries of foreign affairs, but also other ministries, such as justice, economy, trade, environment, trade etc.

How should the International Law Commission design outcomes, and how should the Sixth Committee deal with them?

When the International Law Commission selects a topic motu proprio, it must exercise flexibility in the format of the final products (draft guidelines, draft conclusions etc.) and be guided by the Sixth Committee on what product it desires, if any. Similarly, when the Sixth Committee requests a topic, it should also define, in the request and in a precise manner, what it expects from the Commission.

\section{What should the Commission look like in ten years?}

As a body comprising members of recognized competence in international law, reflecting the main legal systems, and representing all geographic regions, the 2030 Commission, while maintaining the global vision of international law that it has, should continue taking into account the increasing output of other specialized forums (e.g. human rights treaty bodies, the Human Rights Council, the United Nations Commission on International Trade Law (UNCITRAL), and other intergovernmental processes). In this sense, its role should be more focused on specific areas, bearing in mind that other institutions are also taking part in international law-making.

For instance, the Arms Trade Treaty ${ }^{23}$ was negotiated in the First Committee of the General Assembly, as was the case with the Nuclear Ban Treaty. ${ }^{24}$ The Paris Agreement ${ }^{25}$ was negotiated in the framework of the Conference of the Parties of the United Nations Framework Convention on Climate Change, ${ }^{26}$ and the possibility of a Global Pact for the Environment is being considered in an ad hoc open-ended working group under the auspices

23 Adopted 2 April 2013, entered into force 24 December 2014, UNTS registration no 52373.

24 Comprehensive Nuclear-Test-Ban Treaty, adopted 1o September 1996, not yet in force, UN Doc A/5o/1027 (1996).

25 Adopted 12 December 2015, entered into force 4 November 2016, UnTs Registration no 54113 .

26 United Nations Framework Convention on Climate Change, adopted 9 May 1992, entered into force 21 March 1994, 1771 UNTS 107. 
of the General Assembly. ${ }^{27}$ The future treaty on the conservation and sustainable use of marine biological diversity of areas beyond national jurisdiction is being negotiated within the framework of an intergovernmental conference, following the model of the Third United Nations Conference of the Law of the Sea. ${ }^{28}$

Furthermore, at the 2018 Munich Security Conference, the United Nations Secretary-General called for the need to regulate cyber space suggesting it could entail the competence of the First Committee of the General Assembly. ${ }^{29}$ Conversely, the compelling issue of the governance of artificial intelligence, in light of its ethics component, could be considered by the International Law Commission.

In addition, the 2030 Commission should continue to review its working methods, including aspects related to the frequency of its meetings and decision-making (usually by consensus), in order to make its outcomes as relevant as possible for governments.

Other improvements could include an increase in the number of women elected as members and a move towards gender balance. Furthermore, a Commission that works effectively in the six official United Nations languages and encourages multilingualism would be desirable. The Commission should also take into account the diversity of legal systems throughout the different stages of the codification process.

To conclude, the International Law Commission - a body in which Peru has been represented three times, currently by Professor Juan José Ruda Santolaria - has played a fundamental role in the development and clarification of the scope of international law. As the international community continues to evolve, despite threats to multilateralism, and as legal relations continue to become more complex, the work of the Commission will remain a mainstay in the efforts to achieve a rules-based order and a world where the unrestricted respect for international law and, specifically, the Charter of the United Nations, is ensured.

27 The Secretary-General recently issued a report on gaps in international environmental law and environment-related instruments. See UN Doc A/73/419 (2018).

28 UNGA Res 72/249 (24 December 2017).

29 'Secretary-General's address at the Opening Ceremony of the Munich Security Conference [as delivered]' (16 February 2018) <www.un.org/sg/en/content/sg/statement/2018-o2-16/ secretary-general\%E2\%8०\%9gs-address-opening-ceremony-munich-security>. 